\title{
The Social and Public Health Impacts that Occurred in Rantau Utara Subdistrict after the Publication of the Labuhanbatu District Regulations No. 10 of 2011 About the Swallow Bird Tax, Indonesia
}

\author{
Nanda Aulia Yusuf Purba ${ }^{1}$, Humaizi $^{2}$, Kariono ${ }^{2}$ \\ ${ }^{1}$ Master Student in University of Sumatra Utara (USU), Medan, Indonesia \\ ${ }^{2}$ Lecturer in University of Sumatra Utara (USU), Medan, Indonesia \\ Email : Nandaasulia92yahoo.com
}

\begin{abstract}
:
This study aim to find out the social and public health impact that occurred in rantau utara subdistrict after the publication of Labuhanbatu district regulations about the swallow bird tax. The method of this study is qualitative research by using interview data to local government and society. The result of this study there has been no social impact found in the District of Rantau Utara and Rantau Selatan Subdistrict Labuhanbatu Regency since Regional Regulation Number 10 of 2011 concerning Taxes for Swallow Bird Nests imposed.
\end{abstract}

Keywords :

social impact; public health impact; Rantau utara subdistrict; regulation

\section{Introduction}

The failure to achieve the local tax target derived from the exploitation of swallow nests is inseparable from the problem of orderly administration of permits and the proliferation of businessmen who opened swallow nest business in the area without clear permission from the Labuhanbatu Regency Government, so that the local tax target sourced from the far swallow nest tax from achievement. The next problem is the overlapping of policies issued by the Labuhanbatu District Government regarding the spatial layout of the area in Labuhanbatu Regency. Based on the 2013 Labuhan Batu Cipta Karya and Spatial Planning document regarding the results of regional development plans in Labuhanbatu District specifically for the city center, Rantau Utara Subdistrict, serves as the center of regional trade and service activities, and water fronts, while in the Rantau Utara Subdistrict is still found by many shop houses that are used for swallowing bird nests, this certainly contradicts the policy of swallow nests.

The overlapping of the policy illustrates the absence of synchronization of Labuhan Batu Regency Government through SKPD related to Labuhanbatu Regency DPRD in developing and planning regional development in Labuhanbatu Regency. The issue of swallow exploitation in Labuhanbatu Regency is inseparable from the health problems of the surrounding community at the swallow nest concession, because the results of the LIPI study in collaboration with the University of Riau Environmental Center said swiftlets could cause 24 types of disease in humans if the enclosure was not suitable by rules. Disease caused can attack the brain, nerves, and other diseases that exist in swallow birds. The disease is spread through saliva, breath, and swallow droppings. People affected by viruses from swallow usually feel dizzy, weak and tired. If the virus attacks the nerves, the person can become paralyzed. (Nurjito, 2015).

The results of the study clearly show that the people living around the swallow nest business are experiencing problems both from health caused by the existence of swallow nest nests that are in the midst of community settlements and not in accordance with the planned development of the sub-district that has been planned by the Cipta Karya Office and Labuhanbatu Regency Spatial Planning. 
The aesthetic, Cleanliness and beauty problems of the Rantauprapat city which became the capital city of Labuhanbatu Regency in the Rantau Utara District became dirty due to the swallow's nest that perched on electrical cables in the city streets Rantauprapat, and air pollution (noise) produced from tapes (Twitter) Swallow bird caller to enter the swallow nest business shop in the afternoon. This is certainly contrary to the motto of Labuhanbatu Regency, namely Rantauprapat as the Ideal City. The regional regulation of Labuhanbatu Regency No.10 of 2011 concerning Tax for Swallow Bird Nest has not been able to curb the existence of swallow nest nests, even the number of businesses increases every year. The addition of swallow nest nests every year, must have an operational permit and not cause problems for the community around the concession, so that the management and exploitation of swallow's nests does not harm the people who are around the concession, while the profits are obtained by the entrepreneurs. If the Regional Regulation No.10 of 2011 concerning the Tax on Swallow's Bird Nest is not implemented properly, it will create a bigger problem, namely the emergence of conflicts between the community and swallow entrepreneurs. Policies that have been set by the regional government, need to be implemented or implemented to realize order and order in society.

\subsection{Public Policy}

\section{Review of Literature}

In general, the term "policy" used to designate the behavior of an actor (for example an official, a group, as well as a government agency) or a number of actors in a particular area of activity. The term policy is distinguished from the word wisdom meaning wisdom or wisdom. Policy is a general statement of behavior than organization.

According to Carl Friedrich, public policy is a direction of action proposed by a person, group or government in a particular environment that provides constraints and opportunities for policies proposed to use and overcome in order to achieve a goal or realize a goal or specific purpose. (Winarno, 2005: 103)

The term public policy according to (Charles O. Jones in Budi Winarno, 2008:16) explains that the term policy (policy term) is used in everyday practice but is used to replace very different activities or decisions. The term is often exchanged for purposes (goals), programs, decisions (decisions), standards, proposals, and grand designs. Nevertheless, although public policy may seem slightly abstract or may be viewed as something "happened" to a person

\subsection{Social Impact}

The impact in the Kamus Besar Bahasa Indonesia (KBBI) has a strong sense of meaning that brings consequences (both negative and positive. In the social context if the strong influence brings negative consequences, it will cause social problems. Whereas the opposite, it will negate social problems.

According to Soetomo (2008: 1) explained that in general social problems are interpreted as a condition that is not desired by most citizens. This is because the symptoms are conditions that are not in line with expectations or not in accordance with the values, norms and social standards that apply.

In another sense the gap between das sein and das sollen is the trigger for social problems. While Daljuni quoted from Abdulsyani (2002: 185) explains that atri comes from within the community itself is that the problem arises as part of the system where society is oriented. The other important thing that needs to be known in social research is that sometimes a social problem is not realized by the community because they are not aware of the existence of these social 
problems (lack of awareness). This latent social problem has the potential to develop continuously over time which will be difficult and complex to handle.

Parillo (2007: 14) argues that a social condition can be categorized as a social problem if it fulfills the following four elements:

a. This condition is a problem that persists for a certain period of time. The condition that is considered as a problem, but in the future, then it will disappear by itself not including social problems.

b. It is felt that it can cause a variety of physical or non-physical losses, both for individuals and society.

c. It is a violation of the values or social standards of one or several joints of people's lives.

d. Raising the need for solutions.

\section{Research Method}

The location of this research will be carried out in Labuhanbatu Regency, with a focus on the makers and implementers of the Labuhanbatu District Regulation No.10 of 2011 concerning Taxes for Swallow Bird Nest. And sub-districts that have swallow nest business entrepreneurs, as well as people who live in swallow nest concessions. The scope of this study is in Kab. Labuhanbatu with a focus on policy makers, namely the Labuhanbatu Regency DPRD, Labuhanbatu Regency Government, SKPD related to the Port of Batu Regency BPMP2T, District Health Office. Labuhanbatu, businessman for swallow nest business.

\section{Discussion}

The location of this research will be carried out in Labuhanbatu Regency, with a focus on the makers and implementers of the Labuhanbatu District Regulation Number 10 of 2011 concerning Taxes for Swallow Bird Nest. And sub-districts that have swallow nest business entrepreneurs, as well as people who live in swallow nest concessions. The scope of this study is in Kab. Labuhanbatu with a focus on policy makers, namely the Labuhanbatu Regency DPRD, Labuhanbatu Regency Government, SKPD related to the Port of Batu Regency BPMP2T, District Health Office. Labuhanbatu, businessman for swallow nest business.

The noise resulting from tapes (twitter) of the caller of the wallet bird slightly disturbs the citizens around the swallow bird nest building. It is in accordance with the statement from $\mathrm{Mr}$ Mulyono, as the citizens around the wallet bird building say that:

"The sound of the swallow bird caller tapes was pretty unsettling to us, during the afternoon when it wanted to rest the noise was a little disturbing, yes, although it had reported to the chief environmentalist, but until recently there bad been no action of any kind.."

This was also conveyed by Ms. Rosmah, who said that:

"... The sound of the bird disturbed the afternoon. Sometimes it's a little difficult for me to put my child to sleep if he wants to take a nap. Maybe there are also other residents who don't mind, but I think those who object also have this condition ..."

Based on some of the statements it can be concluded that, the noise generated from the wallet bird caller tapes disturbs the residents around the wallet bird nest building when they want to rest.

Besides that, the environmental problems caused by the existence of wallet bird nest buildings must also exist. When the environment is not healthy, it is certain that the health of the 
residents will be disrupted. The scattered rubbish and dripping ditch channels are conditions in the environment where there are swallow nest shops in Rantauprapat. Although not in all locations, however, this still has a widespread negative impact on the region and cannot be used as a justification for the operations of swallow's nest. The pollution of the environment in North Rantau Subdistrict caused indirectly by the exploitation of swiftlet nests. Direct exploitation of swallow nests does not make an impact on environmental pollution, however, there is environmental neglect which results in the non-sustainability of the environment.

The general impacts on environmental pollution caused by the exploitation of swiftlet nests in the city of Rantauprapat include a) scattered garbage, b) clogged ditch canals, c) damaged roads, and d) unhealthy air. The results of this research observation show that the above impacts are real conditions of the establishment of swallow nest business. The unconsciousness of employers and citizens of environmental justice has made the area in Rantau Utara District polluted by the environment.

The scattering of residents' garbage around the shop houses is caused by the lack of awareness of residents and entrepreneurs to care for their environment. The garbage is like it's been chronically in that environment. The condition of waste is scattered like deliberate omission from both the citizens themselves and the government. In fact, the Labuhanbatu Regency Cipta Karya and Spatial Planning Office has allocated temporary waste bins in each environment, as one of the government's efforts to create a clean environment. In fact, on Jalan Kopral Abdullah it was found trash scattered next to the shophouse swallow.

Through interviews with the Labuhanbatu District Human Settlements and Spatial Planning Office related to the occurrence of environmental omission in the vicinity of the swallow nest concession, Mr. A. Sitanggang said:

"Our duties and functions are actually facilitators. We first looked at the swallow environment, there were people who were deserted, there were also people who were close to the population. For that, we are running in accordance with government programs, the environmental control that we do is only from waste. provision of temporary bins for residents. For environmental control the impact of swallow is actually sheltered by other SKPD. Because once again, we ourselves do not yet know clearly how the exploitation is. The government should reinforce the regulations first. There must be the identity of the swallow shop, so that we can see the impact. So that the impact can be controlled."

In line with the scattered garbage, the ditch around Jalan Kopral Abdullah also went abnormal. In addition, the road conditions that are not on asphalt make this area like an uninhabitable environment. This is due to the fact that in this region there are around 30 shop houses for swallowing nests. The condition of the lonely environment was used as an excuse for not taking care of environmental health.

On Jalan Sanusi, where in this environment there are at most swallow nest business concessions, even the environment is contaminated. Air pollution is a massive pollution in this area. With the establishment of around 30 three-storey or more swallow nest-shop houses, it can already be imagined how the air conditions in the teresbut environment. Hundreds of swallows every day passing by on this street, especially in the morning and evening. At that time swallow enter and exit the shop houses.

Rantau Utara Subdistrict and Rantau Selatan Sub-District have the most population among the Sub-Districts in Labuhanbatu Regency. Population density is in line with the local government program which sets this sub-district as a city service center. Being the opposite when, the status of 
urban areas is not balanced with environmental conservation programs. Urban communities need a clean and healthy environment, given that urban activities take up a lot of time.

The impact resulting from the exploitation of swiftlet nests in the Rantau Utara District and Rantau Selatan District resulted in the urban environment becoming polluted. Starting from sound pollution to the indirect impacts caused by swallow business, namely, the occurrence of environmental omission. As a result, the environment is poorly maintained, garbage is scattered, clogged ditches have an impact on the deterioration of the quality of life of the people in the Rantau Utara District and Rantau Selatan District.

The possible defense for this business is that this business makes Labuhan Batu a supplier of swallow nests and so far there has never been a significant impact on this business. The predicate above may be seen as a positive thing for Labuhanbatu, but the local government itself does not seem to pay attention to the tranquility of the urban environment, especially the Rantau Utara District and Rantau Selatan District.

In line with the above quote, Badan Lingkungan Hidup (BLH) of Labuhan Batu Regency through this research interview stated that:

"We do not have a share in the operations of swallow's nest in Labuban Batu. BLH stated that they were more persuasive, meaning that every practice of environmental exploitation that took place in Labuban Batu Regency would eventually become a joint suffering. This is what makes environmental management in autonomous regions not yet reflected the integration of the principles of environmental protection and ecological sustainability."

The issue of swallow exploitation in Labuhanbatu Regency is inseparable from the health problems of the surrounding community at the swallow nest concession, because the results of the LIPI study in collaboration with the University of Riau Environmental Center said swiftlets could cause 24 types of disease in humans if the enclosure was not suitable by rules. Disease caused can attack the brain, nerves, and other diseases that exist in swallow birds. The disease is spread through saliva, breath, and swallow droppings. People affected by viruses from swallow usually feel dizzy, weak and tired. If the virus attacks the nerves, the person can become paralyzed. (Nurjito, 2015)

The results of the study clearly show that the people living around the swallow nest business are experiencing problems both from health caused by the existence of swallow nest nests that are in the midst of community settlements and not in accordance with the planned development of the sub-district that has been planned by the Cipta Karya Office and Labuhanbatu Regency Spatial Planning.

The existence of noise pollution is a definite consequence of the establishment of a swallow nest business shop. Sound pollution seems to be considered an insignificant thing. Seeing the interference caused can only be felt by the ear senses. Sound pollution from swallow shop houses is sourced from tweeters or swallow angler music, which function as flying swallow callers.

Based on research carried out by the University of Riau's Center for Environmental Research, the Public Perception of Noise in Swallow's Nest in Rimba Village, Dumai, Riau, stated that the breeding noise of swiftlets in community settlements would give rise to people's perceptions of physiological aspects, aspects psychological, and aspects of sound noise. The noise disturbance is a comfort disturbance to the people who live around the concession. 
Tabel. 1

Recapitulation of physiological perception scores on business noise of swallow bird nests in Dumai City, Riau

\begin{tabular}{|c|c|c|c|c|c|c|}
\hline \multirow[t]{2}{*}{ Indicator } & \multicolumn{5}{|c|}{ Perception } & \multirow[t]{2}{*}{ Total } \\
\hline & SS & $\mathbf{S}$ & $\mathbf{N}$ & TS & STS & \\
\hline A sense of Discomfort & 45 & 260 & 21 & 18 & 5 & 349 \\
\hline Headache & 55 & 220 & 36 & 20 & 7 & 338 \\
\hline Blood Pressure Rising & 55 & 180 & 39 & 30 & 11 & 315 \\
\hline Hearing Disorder & 50 & 164 & 63 & 22 & 12 & 311 \\
\hline Total & 205 & 824 & 159 & 90 & 35 & 1313 \\
\hline \multicolumn{7}{|c|}{ Source: University of Riau Center for Environmental Research 2013} \\
\hline \multirow[t]{2}{*}{ Indicator } & \multicolumn{5}{|c|}{ Perception } & Total \\
\hline & $\overline{\text { SS }}$ & $\mathbf{S}$ & $\mathbf{N}$ & TS & STS & \\
\hline Emotional Disorders & 155 & 92 & 54 & 28 & 9 & 338 \\
\hline Stress & 135 & 92 & 66 & 22 & 12 & 327 \\
\hline Lack of concentration & 145 & 104 & 51 & 30 & 8 & 338 \\
\hline Break Disorders & 160 & 116 & 60 & 18 & 5 & 359 \\
\hline Total & 595 & 404 & 231 & 98 & 36 & 1362 \\
\hline
\end{tabular}

Source: University of Rian Center for Environmental Research 2013

The research by the University of Riau's Environmental Research Center aims to analyze the noise frequency of swallow nest breeding and analyze community perceptions of the noise of swallowing bird nesting operations in the Rimba of Dumai City. By using a Sound Level Meter (SLM) tool, the average noise level obtained at a 30 meter radius is $69.21 \mathrm{~dB}$, a 60 meter radius of $60.54 \mathrm{~dB}$, and a 90 meter radius of $53.80 \mathrm{~dB}$. From the average value of the noise frequency it can be concluded that the radius of 30 and 60 meters has exceeded the noise threshold in the urban area of $55 \mathrm{~dB}$.

The case in Riau, the operation of swallow nests in operation has concession permits from the government. This is what makes entrepreneurs not feel that they have had a bad impact on the surrounding environment. Meanwhile, the results of the study show that almost the majority of Dumai City residents agree that noise caused by exploitation of swallow nests is very disturbing.

The same thing with the Rantauprapat City area, one of which was in the Cendana village. Head of Cendana Village explained that the most visible impact on the exploitation of this swallow was the noise. Since he was a child, he heard the noise of the business. Because it is already like that how to call swallow, so that swallow wants to enter into the shop and produce swallow nests. In addition, the number of commercial shop houses in Cendana Village is around forty. Consequently, throughout the day people are forced to enjoy the noise of tweeters from forty swallow nest shops.

The following are the results of interviews with Lurah Cendana in Rantau Utara Subdistrict:

"In keluraban Cendana, it has been a long time since many of the swallow shophouses. Even since I was little, the china ranto here has had many swallow shophouses. Even once more than now. Here too, the majority of the Chinese, so the bandwagon shophouse in this area is commonplace. If it's about impact, it 
seems that it's actually noise. So far, from me even small, it's just the impact.It's the noise that's noisy. Because he's calling wild birds, so it's gotta be strong that sound so swallow that flies."

But unlike in the case in Dumai City, already one step ahead in noise disorder research, Rantauprapat City does not seem to feel the least bit distracted. It does not appear that the daylight and local people protested against the noise they received all along. Whereas they live in urban areas, which are notabene the quality of life is better than those living in the countryside. There is nothing at all that programs are geared towards this entrepreneurship of the walet, when it is obvious that these employers are directly tangent to the environment. Even BLH has never done any research on the environment at all. Whereas urban activity in Rantauprapat is already feasible to research its environment, given the high activity of citizens and offices and the high flow of transportation.

Talking about the impact, BLH, which is actually a government institution that oversees environmental problems, actually has absolutely no contribution in this business. Through interviews at the BLH Office, Mr. M. Sitompul stated:

"BLH has so far not had a role in exploiting swallow nests. Because of our knowledge, this effort has never been touched upon. There have never been protests from residents with us. BLH had received a report about $C$ excavated waste that was disturbing residents. That's all we've ever received. However, we once carried out counseling on environmental health in the area of shop swallows. At that time, we were running an environmental sustainability socialization program. This BLH appeals to the truth, if the action is direct, it is not our authority. After all, this swallow business is actually just a shop business. It's just their work to put on swallow music. Already that, as far as we know there has been a probibition to try swallow in the City. So, they are illegal. The licensing agency actually has to go down there. We can monitor their activities only. Either the danger of the air was because of that, whether the droppings fell into people's yards. We don't know either. People have never reported with us.

Interview with Labuhanbatu District Health Office:

"If looking from our environmental health indicators, we can actually see that it has nothing to do with environmental health with the swallow's efforts. But if we review again, it could actually be something to do. I'm sure, the area where the ballet's stamps are not necessarily sterile of disease disorder. Nor do we know how the conditions within the stamp are. Is in it a nesting place and breeding mosquito, we haven't researched that yet. .But indeed so far, the efforts of the swallow here have not had any impact on health."

There was a refraction from the Stone Labuhan District Health Service regarding health threats that were at all times lurking over the entrepreneurship of swallow nests in Rantauprapat City. From the results of the interview, it appears that the business activities of swallow nests as unimpacted to environmental health

Next was an interview with Mr. Muksin, as an expert and entrepreneur of swallow nests in the Cendana Sub-District of Rantau Utara District as follows:

"Actually, there is no waste in this swallow. Swallow droppings are like ash. If we hold it, exactly like ash, it is immediately squeezed out. The dirt is only in the shop, where does he want to land. Even if there is, it is rarely. Usually when we harvest, we clean the place of swallow, the dirt is collected and put into the burlap. We usually dispose of it to the garbage disposal site in the weed. All of you, replace the water in those buckets. The impact is actually no. Only noise from the angler's voice. Even then, we have set the hour. At 8:00 p.m. it was already dead, on average, all those shop houses were swallowed. But indeed if on the road Sanusi, 24 hours. Because there is the most swallow shop. For air or water pollution, only a little. Because swallow wants to go out occasionally to look for food in rivers or ponds, reservoirs. If the bealth effects have so far never been a case. In fact, people who harvest swallow nests have never had any 
pain. Moreover, many of the shop houses are occupied by those who have them underneath. So the health problem is no interference."

From the statistical data of the ten most diseases in Labuhan Batu Regency indicates that environmental health is the strongest reason that these diseases occur very much. Acute upper respiratory tract infection (ARI) received the best-selling predicate with the number of cases 19,203. This disease is caused by the poor quality of clean air consumed by residents, plus the behavior of unhealthy people. Compounded again, this disease is a type of disease that can be transmitted freely to anyone who is contaminated from objects that suffer from this disease.

Through interviews with the Health Office related to the absence of research conducted on the effects of diseases that can be transmitted by swallow, Mr. Lindung stated:

"Not yet. We have never made such research. Because of that earlier, so far there has never been a known impact on health in Labubanbatu. But that does not mean I conclude that Labubanbatu is free from diseases such as the LIPI study. But later we will try to coordinate with relevant parties, SKPD-SKPD, to research this. Because indeed, if you speak of illness, he can not appear directly, he could bave developed inside and in time just found out. According to data on the 10 most common diseases in Rantauprapat, one of them is ARI, culture allergies, diarrhea. For this ARI disease, it covers the middle to advanced ages. Allegedly the main cause of this disease is because of the dirty air it breathes, causing respiratory inflammation. Well, if you are like this, this can be transmitted to other people, when he communicates, now it depends on people's endurance. If the antibody is strong, it is usually resistant, if the weak are usually infected. It also depends on activity and work too. Usually, these field workers, porters, and those who have been active in smoking for 30 years often suffer from ARI. For skin allergies, diarrbea, this is due to cleanliness of water, food and air. It could be caused by unhealthy eating, careless behavior. But so far, no one has ever admitted to being sick with ARI or allergies because of the shop bouse.

The Labuhanbatu Health Office claimed that there had never been a case of disease caused by swallowing of swallow nests in Rantauprapat City, but seeing ARI disease which ranked first in the highest number of diseases, it seemed necessary to do further studies on the causes of this disease. In line with that, it is necessary to prove that the research carried out by LIPI that exploiting swiftlet nests in residential areas will have a negative impact on the health of the surrounding community. LIPI states that swift birds can deliver viruses, which can attack the brain, nerves and other diseases.

\section{Conclussion}

Leading sector for implementing Regional Regulation No. 10 of 2011 concerning Taxes for Swallow's Nest is the Investment Board and Integrated Licensing Services of Labuhanbatu Regency assisted by other agencies such as the Environmental Agency, Cipta Karya and Spatial Planning of Labuhanbatu Regency

Until now there has been no social impact found in the District of Rantau Utara and Rantau Selatan Subdistrict Labuhanbatu Regency since Regional Regulation Number 10 of 2011 concerning Taxes for Swallow Bird Nests imposed.

Book Resources :

\section{References}

Bungin, Burhan. 2008 . Metodologi Penelitian Kuantitatif: Komunikasi, Ekonomi, Kebijakan Publik Serta Ilmu-Ilmu Sosial Lainnya. Jakarta: Kencana 
Creswell, W John. 2009. Research Design: Pendekatan Kualitatif, Kuantitatif, dan Mixed (Achmad Fawaid, Penerjemah). Yogyakarta: Pustaka Pelajar

Dunn, William N. 2003. Analisis Kebijaksanaan Publik. Yogyakarta: Hanindita Graha Widya

Fadhilah, Putra. 2005. Paradigma Kritis dalam Studi Kebijakan Publik dan Ruang Partisipasi dalam Proses Kebijakan Publik. Yogyakarta: Pustaka Pelajar

Indiahono, Dwiyanto. 2009. Kebijakan Publik Berbasis Dynamic Policy Analisys. Yogyakarta: Gava Media

Islamy, Irfan, 2003. "Prinsip-Prinsip Perumusan Kebijakan Negara". Jakarta:, Bumi Aksara,.

Ismail, Fauzi. 2005. Libatkan Rakyat dalam Pengambilan Kebijakan.. Yogyakarta: UGM-Press

Laswell dan Raplan. 2001. Pengambilan Kebijakan. Jakarta: Ghalia Indonesia

Moenir. A.S. 2002. Manajemen Pelayanan Umum di Indonesia. Jakarta: Bumi Aksara.

Moleong, Lexy, J. 2010. Metodologi Penelitian Kualitatif (Edisi Revisi). Bandung: Remaja Rodakarya

Mulyana. 2003. Design Penelitian Sosial Jakarta: Gramedia

Neuman, W. Lawrence. 2006. Social Research Methods : Qualitative and Quantitative Approaches. (Sixth Edition). United States of America : Pearson Education, Inc.

Randall B. Ripley. 1985. Policy Analysis in Political Science. Chicago: Nelson-Hall Publisher.

Safrina, Dian 1999. Post Modernisme dalam Pengembangan Wacana Formulasi Kebijakan. Yogyakarta: UGM-Press

Santoso, Purwo, dkk. 2004. Menembus Ortodoksi Kajian Kebijakan Publik Yogyakarta: Fisipol UGM Santoso, Amir. 2001. Analisis Kebijakan Publik.Jakarta: Gramedia

Silalahi, Ulber. 2010. Metode Penelitian Sosial. Bandung: PT. Refika Aditama

Solichin, Abdul Wahab. 1990. Pengantar Analisis Kebijaksanaan Negara. Jakarta: Rineka Cipta

Subarsono, AG. 2003. Analisis Kebijakan Publik. Yogyakarta: UGM-Press.

Sugiyono. 2008. Metode Penelitian Kualitatif dan Kuantitatif”. Bandung: CV Alfabeta

Sunggono, Bambang. 2004. Hukum dan Kebijakan Publik. Jakarta: Sinar Grafika

Suparlan. 2001. Pelayanan Umum Masyarakat. Jakarta: Miswaka

Sumaryadi, I Nyoman. 2005. Efektivitas Implementasi Kebijakan Otonomi Daerah. Depok: Citra Utama Syamsi, Ibnu. 1993. Kebijaksanaan Publik dan Pengambilan Keputusan Yogyakarta: Fisipol UGM

Thoha, Miftah, 1992. Dimensi-Dimensi Prima Ilmu administrasi Negara. Jakarta: PT. Raja Grafindo Persada.

Thoha, Miftah. 2000. Birokrasi dan Politik di Indonesia. Jakarta: Rajawali Press

Topatimasang, Roem. 2000. Merubah Kebijakan Publik. Yogyakarta: Pustaka Pelajar

Wahab, Solichin A. 2001. Pengantar Analisis Kebijakan Negara. Jakarta: Rineka Cipta

Wibawa, Samodra, dkk. 2002. Evaluasi Kebijakan Publik. Jakarta: Raja Grafindo Persada

Winarno, Budi, 2004. Teori dan Proses Kebijakan Publik. Yogyakarta: Media Pressindo

\section{Journal Resources:}

Fairus Firda Rizki, 2015. Pengelolaan dan Pengusabaan Sarang Burung Walet Dalam Meningkatkan Pendapatan Asli Daerah di Kecamatan Penaja Kabupaten Penajam Paser Utara. E-Journal Ilmu Penerintahan 3, (2), 2015:863-873 UNDIP

Ja'far Arief dan Isril, 2013. Implementasi Perda Pengelolaan dan Pengusahaan Sarang Burung Walet. Jurnal Demokrasi \& Otonomi Daerah Vol 11 Nomor 1 Juni 2013 hlm 1-70. FISIP UNRI

Thesis Source :

Halimah, 2013. Implementasi peraturan daerab kabupaten siak nomor 4 tabun 2008 tentang izin pengusabaan pengusabaan sarang burung walet di kecamatan Tualang Tesis. Universitas Islam Negeri Sultan Syarif Kasim Riau.

Nazhilla. 2015. Implementasi Kebijakan Pajak Sarang Burung Walet di Kota Padang Skripsi, FISIP Universitas Andalas Padang 
Nurul Hidayati. 2011. Implementasi Kebijakan Pengelolaan Burung alet Habitat Alami di Kabupaten Ogan Komering Ulu Propinsi Sumatera Selatan Tesis Prodi Ilmu Lingkungan UNDIP Semarang

Purnama, Hendry. 2013. Implementasi Peraturan Daerah Kabupaten Sukamara Tentang Pengelolaan Sarang Burung Walet di Kecamatan Sukmara Tesis. Universitas Terbuka

Reza Gustina. 2016. Implementasi perda kabupaten inbil nomor 22 tahun 2010 tentang pajak sarang burung walet (studi kasus di kecamatan keritang).Tesis, Universitas Islam Negeri Sultan Syarif Kasim Riau.

\section{Internet Resource:}

Nurjito. 2013. Persepsi Masyarakat Terbadap Pengusabaan Sarang Burung Walet dan Jenis Penyakit Yang Dapat Ditularka Oleh Burung Walet.”. RepublikaOnline.Dapatdiaksesdi:http://www.ligagame.com/forum/index.php?topic61300.10;wap2. Berita diakses pada 2 Mei, 2017 Pkul 14.30. W.I.B

Agung, Anak Banyu Perwita dan Yanyan Moch. Yani. 2005. Pengantar Ilmu Hubungan Internasional. Bandung : Rosda. Hal.135-159.

A, Theodore Couloumbis dan James H. Wolfe. 1990. Pengantar Hubungan Internasional: Keadilan dan Power, edisi pertama. Bandung: Abardin. Hal. 392-413.

bio.undip.ac.id/sbw/sp_daftar_indo.htm

Dauvergne, Peter. 2005. Globalisation and Environment dalam John Ravenhill, Global Political Economy. Oxford: University Press, hal. 370-395.

Hakim, Lukman. 2017. Pajak Daerah Sarang Burung Walet. Dapat diakses di http://padjakdaerah.blogspot.co.id/2017/03/pajak-sarang-burung-walet.html.

Lutfi, Muhammad. 2008. Memperbesar Gerakan Politik Lingkungan. Melalui < http://sansigner. wordpress.com/2008/05/04/memperbesar-gerakan-politik-lingkungan/>. [25 Mei 2017 pukul 19.30].

Situmorang, Sansen. 2008. Ekologi Politik. Studi Kasus : Gagasan CSR Dalam Meredam Gejolak Sosial Masyarakat Lokal. Melalui < http://sansigner.wordpress.com/2008/06/06/ekologipolitik-studi-kasus-studi-kasus-gagasan-corporate-social-responsibility-csr-dalammeredam-gejolak-social-masyarakat-lokal-masyarakat-indonesia-timur/>. [25 Mei 2017 pukul 19.29].

\section{Regulation Resources:}

Lampiran 1. Perda Nomor 10 Tahun 2011 Tentang Pajak Sarang Burung Walet di Kabuipaten Labuhanbatu. 